\title{
JUURNAL.RU
}

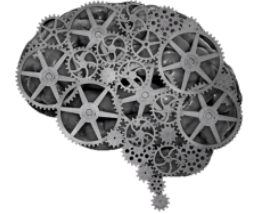

COMPANY GROUP "INTELLEKT"

\author{
Танасова А.С. ${ }^{1}$, Зайцев И.В. ${ }^{2}$ \\ ${ }^{1}$ Астраханский Государственный Технический Университет \\ ${ }^{2}$ ГБУЗ АО «Областной онкологический диспансер» \\ Астразань, Россия
}

doi: 10.18411/1j2016-5-3-18

\section{Влияние антропогенного загрязнения вод металлами на здоровье населения индустриально-нагруженного региона}

Химический состав природных вод на городской территории формируется в условиях сложных взаимодействий естественных потоков с многочисленными источниками техногенной нагрузки. Характер этих взаимодействий во многом определяется как конфигурацией временных и постоянных действующих водотоков, так и гидродинамической структурой фильтрационных потоков. Это обстоятельство требует более пристального внимания к анализу условий формирования поверхностного стока в условиях их тесного взаимодействия [1]. Одной из причин актуальности исследования р. Волга, а в особенности Дельты Волги, является её географическое расположение, которое влияет на качество воды, степени её загрязненности и здоровье населения.

В связи с этим ставиться следующая цель проанализировать содержание тяжелых металлов в р. Волга г.Волгограда и г.Астрахани, выявить влияния загрязненной питьевой воды на организм человека.

Были поставлены следующие задачи:

- проанализировать содержание тяжелых металлов в р. Волга г.Волгограда и г.Астрахани, на примере $\mathrm{Fe}, \mathrm{Cu}, \mathrm{Zn}, \mathrm{Mg}, \mathrm{Ca}$;

- показать особое значение изучения загрязнения Дельты Волги;

- оценить динамику загрязнения тяжелыми металлами системы «вода организм», на примере $\mathrm{Fe}, \mathrm{Cu}, \mathrm{Zn}, \mathrm{Mg}, \mathrm{Ca}$. 
Качество и загрязненность поверхностных вод p. Волга зависят непосредственно от антропогенной деятельности всех субъектов расположенных вдоль русла, но наибольшей нагрузкой подвержены нижерасположенные субъекты, в частности Астраханская область.

Анализ содержания тяжелых металлов в период с 2010 по 2014 гг. в р.Волга г.Волгограда и г. Астрахани, показывает то что превышение ПДК наблюдается в обоих промышленных городах. Преобладает загрязнение $\mathrm{Fe}, \mathrm{Cu}$, $\mathrm{Zn}, \mathrm{Mg}$, Са в Дельте Волги Астраханская область, что показано в диаграмме 1.

Диаграмма 1

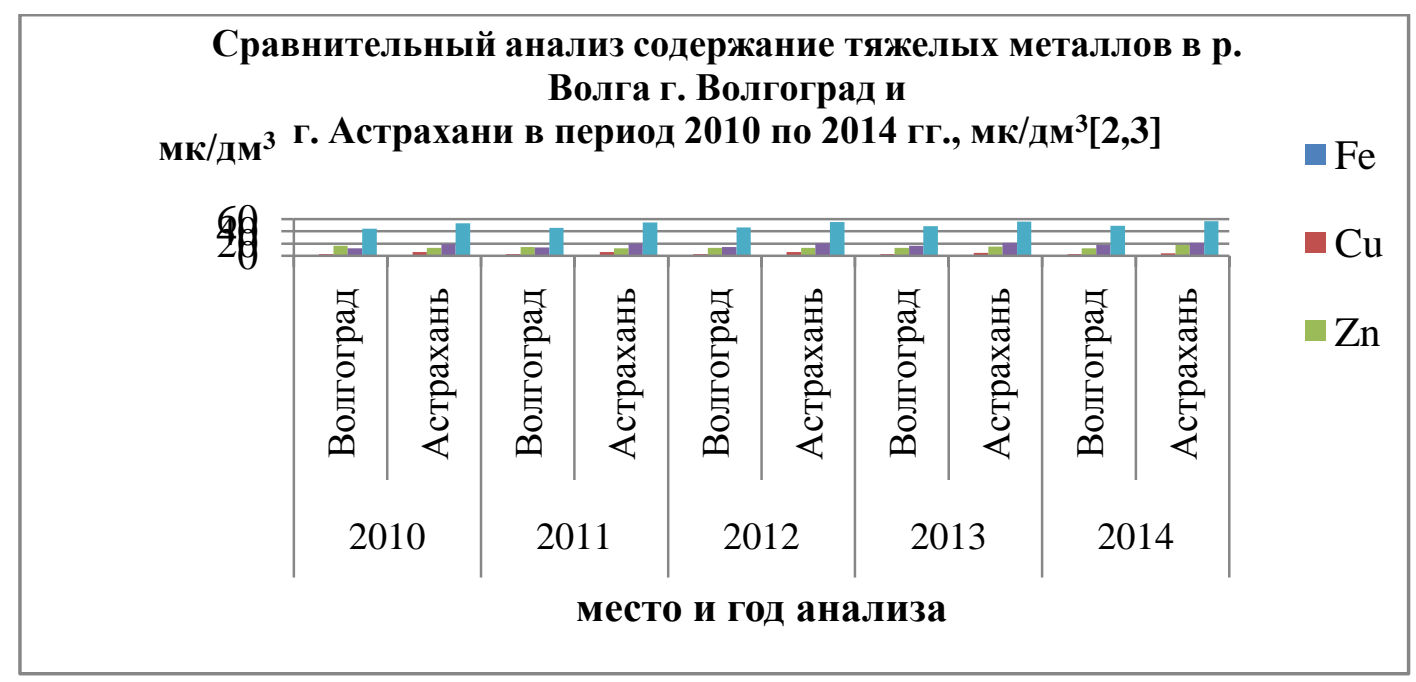

Диаграмма 2.

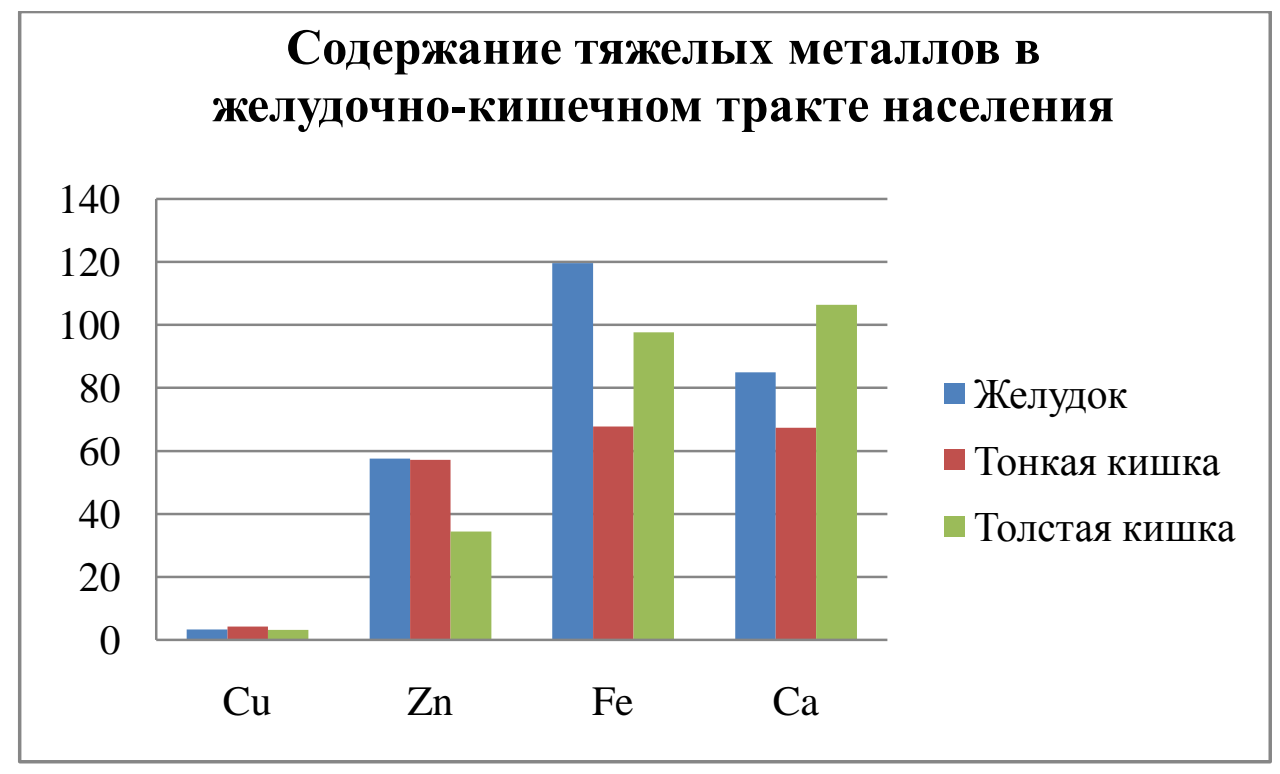


Такие значительные колебания концентрации элементов объясняется географическим расположением городов и ярко показывает значимость изучения проблемы загрязнения Дельты Волги в Астраханской области, которое непосредственно влияет на здоровье населения (диагр. 2).

Из диаграммы 2 видно, что концентрация металлов в воде Нижней Волги влияет на концентрацию этих же элементов в желудочно-кишечном тракте жителей г. Астрахани, так как прослеживается зависимость содержания тяжелых металлов в воде и в органах человека.

Полученные данные позволяют сделать предположения, о связи геохимической обстановки со здоровьем населения в изучаемом регионе. Так как пестициды, удобрения, тяжелые металлы и органические соединения могут накапливаться в воде, в организме сельскохозяйственных животных, овощах и фруктах местного производства и в дальнейшем мигрировать в организм человека.

В связи с этим обостряется медико-экологическая обстановка, отличительной чертой которой будет являться, в том числе, увеличение числа людей с онкозаболеванием. Одними из ведущих факторов провоцирующих онкозаболевемость являются тяжелые металлы и радионуклиды, источники которых могут быть естественного и искусственного происхождения [5]. Загрязнение питьевой воды Нижней Волги тяжелыми металлами ведет к различным болезням среди населения. 


\section{Литература}

1. Геологическое исследование водных объектов Великого Новгорода. Мячков В.П. Географическое изучение территориальных систем: Сборник материалов 5 Всероссийской научно-практической конференции студентов, аспирантов и молодых ученых, Пермь 2011. Пермь, 2011. С. 100-102.

2. Государственный доклад «Об экологической ситуации в Астраханской области в 2010 - 2014 годах» Ред. колл.: И.О. Краснов [и др.]; службой природопользования и охраны окружающей среды Астраханской области совместно с НО АНО «Центр экологического образования населения Астраханской области». - Астрахань: НО АНО «Центр экологического образования населения Астраханской области», 2011 -2015 гг.

3. Доклад «О состоянии окружающей среды Волгоградской области в 2010 2014 годах» Ред. колл.: О.В. Горелов [и др.]; Комитет природных ресурсов и охраны окружающей среды Администрации Волгоградской области. Волгоград: «СМОТРИ», 2011-2015 гг.

4. Зайцев И.В. Кумуляция микроэлементов в крови при некоторой патологии мочевыделительной системы/ И.В. Зайцев, В.А. Зурнаджьянц, В.В. Кутуков, В.Е. Кутуков // Астраханский Медицинский журнал. - 2015. - Т.10, №2. - С. $47-51$

5. Кудрин, А. В. Микроэлементы в иммунологии и онкологии / А. В. Кудрин, О. А. Громова. - М.: ГЭОТАР-Медиа, 2007. - 544 с. 